Intrahospital triage gjøres i det pasienten ankommer akuttmottaket og blir ivaretatt av sykepleier som rapporterer videre til lege.

\section{www.sykepleien.no}

\section{Les mer og finn}

litteraturhenvisninger på

www.sykepleien.no

\section{Søkeord:}

Akuttsykepleie

Klassifiserig

Organisering

\title{
Rett bemanning til riktig tid
}

\section{Triage-systemet METTS-A er innført i Akuttmottaket ved Sørlandet} Sykehus Arendal for å forbedre kvaliteten på pasientprioriteringen.

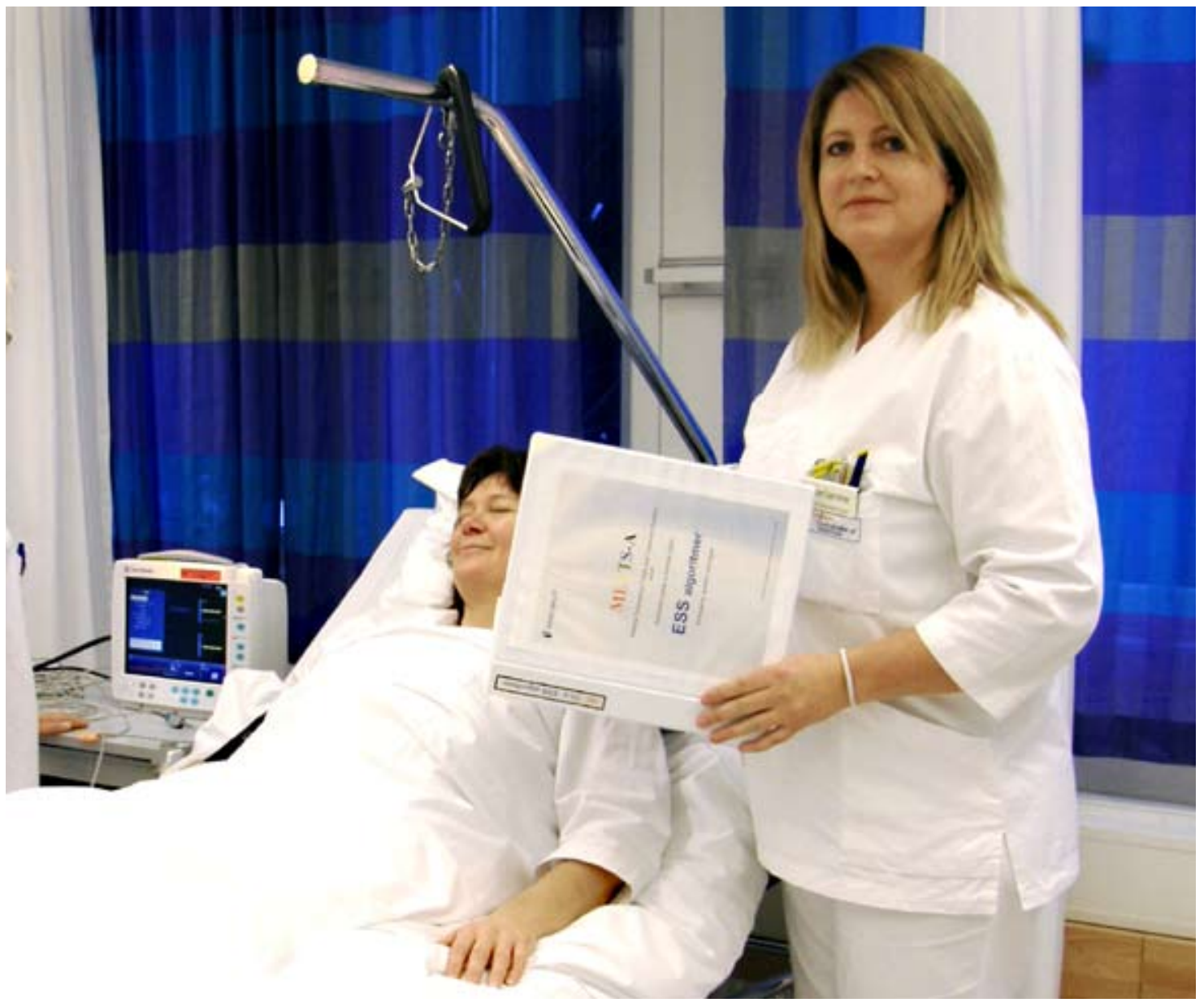

SER PASIENTEN: I Akuttmottaket ved Sørlandet Sykehus er triagesykepleieren en viktig premissleverandør for legens prioritering og vurdering her representert ved anestisykepleier Marianne Sundseth. Foto: Torunn Vatnby

Helsetilsynet gjorde i 2007 en gjennomgang av driften ved Akuttmottakene i Norge. Ved tilsynet ble avvik fra forsvarlig drift på flere punkter avdekket i de fleste enheter (1). Uforsvarlig pasientmottak og mangelfull dokumentasjon var gjengangere. Dette medførte at flere akuttmottak startet med å etablere systemer for intrahospital triage. Akuttmottaket ved Sørlandet Sykehuset Arendal har valgt å bruke en modell utviklet ved Sahlgrenska universitetssjukehus i Gjøteborg: Medical Emergency Triage and Treatment System (METTS).

\section{Historikk}

Emergency departemet triage
(Intrahospital triage) ble introdusert i USA i 1950-årene som et resultat av at et økende antall pasienter oppsøkte akuttmottakene. Økningen av pasienter førte til et behov for å sortere pasienter på en sikrere og mer effektiv måte (2). I ettertid har man erkjent dette behovet ved akuttmottak i flere land og innført 
ulike former for intrahospital triage $(3,4,5)$.

Det finnes flere ulike modeller for triage (3) og Helsetilsynet påpeker at forskjellige organisatoriske løsninger for pasientprioritering $\mathrm{i}$ utgangspunktet kan velges dersom en minstestandard blir overholdt (1). Det foreligger ingen dokumentert oversikt over bruk av triage i Norge. Vi vet at det finnes flere lokalt utviklet måter å prioritere pasientene på, og at flere av disse systemene har innslag av ulike dokumenterte modeller.

\section{METTS-A}

METTS (Medical Emergency Triage and Treatment System), som er den modellen vi har valgt på Akuttmottaket ved Sørlandet Sykehus Arendal, ble utviklet i 2004 ved Sahlgrenska universitetssykehus og implementert i 2005. METTS er en protokoll for beslutningsstøtte innen alle typer akuttmedisin både prehospitalt og intrahospitalt.

METTS-A gir grunnlag for sortering, prioritering og risikoidentifisering av alle voksne pasienter i akuttmottak. Formålet med protokollen har vært å oppnå høyere grad av systematikk, sensitivitet og kontroll i mottakelse av pasienten og økt medisinsk sikkerhet i den fortsatte prosessen. Studier viser at METTS-A fungerer godt når det gjelder å kartlegge de sykeste pasientene både på akuttmottaket og under den etterfølgende behandlingstiden(4).

Triage-modulen i METTS-A baserer seg på dels fysiologiske objektive vitalparametre og dels subjektive parametere knyttet til akuttsymtom: Emergency symptom and signs (ESS). Prioriteten i henhold til METTS styrer tiden til lege, graden av monitorering

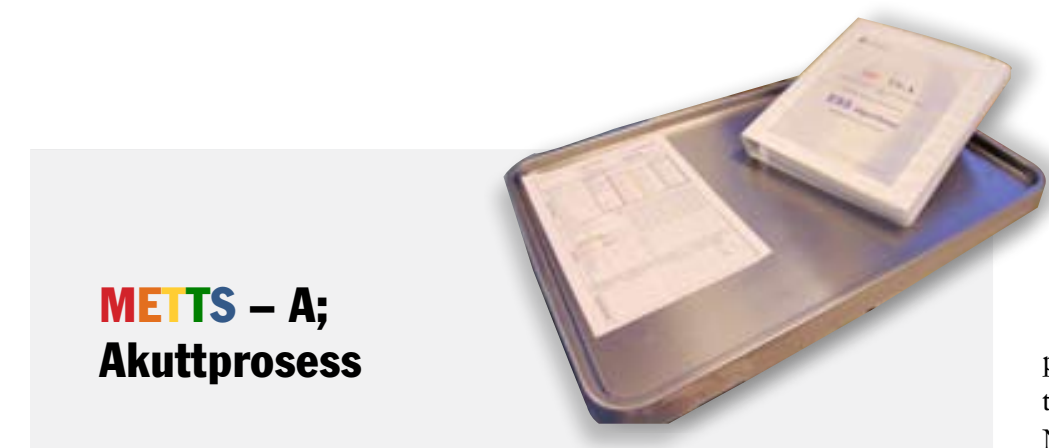

$\mathbf{R ø d}=\quad$ livstruende tilstand som krever full monitorering (telemetri, ev. ischemi- overvåking BT, Sp02, RF, bevissthet) og sykepleiere "bedside" til medisinsk ansvarlig gjort pasienten oransje eller lavere. Legetilsyn: Time to doctor (TTD) $=0$ minutter

Oransje = overvåkningsbehov som også krever full monitorering (ditto rød) men med intervall på 20 minutt, samt pasientansvarlig sykepleier med tilsynsansvar inntil TTD. TTD $=<20$ minutter

$\mathrm{Gul}=\quad$ standardprosess med kontroller og videre kontroller ved behov, selektiv monitorering og kontroll av den/de parameterne markerer i triagegradering inntil TTD. TTD $=<120$ minutter

Grønn = standardprosess uten kontroller. Ingen monitorering men regelmessig tilsyn av pleier. TTD $=<240$ minutter

Blå = ikke behov for triage [6]

samt eventuelle blodprøver. (4). Protokollen inneholder 96 kontaktårsaker (ESS). ESS skal kunne gi en høyere grad av prioritet selv om vitalparametrene ikke slår ut. Det vil si at selv om pasientens blodtrykk, puls, bevissthet og respirasjon er innen normalområdene kan pasientens tilstand allikevel være alvorlig. Algoritmene i ESS protokollen skal fange opp dette, og eventuelt gi pasienten høyere prioritet (6). Underveis i prosessen med å implementere METTS i akuttmottaket ved SSA har vi foretatt noen tilpasninger. Vi har blant annet endret skalaen til en skala med fire nivåer i stedet for fem: blå kategori er tatt bort. Begrunnelsen er at pasienter som faller under denne gruppen i praksis vil være kandidater for legevakten, og at disse derfor i svært liten grad oppsøker akuttmottaket. Blodprøveprofilene som rutinemessig bestilles på pasienter med henholdsvis kirurgiske eller medisinske problemstillinger endres ikke i henhold til METTS-A, her følges tidligere praksis. Men det at vi i utgangspunktet har valgt å tilpasse systemet noe, utelukker ikke at de erfaringene vi gjør fremover vil føre til nye endringer.

\section{Hvorfor METTS-A?}

Helsetilsynet har stilt krav om at akuttmottak skal foreta riktig pasientprioritering (1). Pasientene kommer til sykehus på grunn av behov for spesialisthelsetjeneste.
Når pågangen er stor kan legeressursene i spesialisthelsetjenesten være knappe, og det må derfor gjøres en initial sortering slik at legen kan prioritere tiden sin riktig i forhold til pasientens behov for helsehjelp. Når pasienten kommer til akuttmottaket er det sykepleieren som først ser og tar imot pasienten. Intrahospital triage gjøres idet pasienten ankommer akuttmottaket og blir ivaretatt av sykepleier som rapporterer videre til lege. Det vil i praksis si at sykepleier gjør graderinger basert på et medisinsk grunnlag. Derfor er det viktig at den graderingen som gjøres er basert på en dokumentert og validert standardmodell som sikrer riktig gradering av pasienten. Roller og ansvarsfordeling endres ikke: Legen forstår sykdomsbilder og beslutter behandling (7), sykepleieren tar vare på pasientene spesielt i den sårbare fasen før slik vurdering kan bli gjort. I intrahospital triage er triagesykepleieren en viktig premissleverandør for legens prioritering og vurdering.

Helsepersonell i akuttmottakene har varierende kvalifikasjoner og erfaring (1). Et system som gir godt samsvar i graderinger, uavhengig av hvem som graderer, styrker kvaliteten på pasientmottak. Betydningen av objektive registreringer av vitalparametre er underbygget i flere studier. Blodtrykk, puls, respirasjonsfrekvens og så videre, er målinger helsepersonell i akuttmottaket gjør til daglig på alle pasienter og har gode rutiner på, og disse målingene gir objektiv informasjon. Modeller som legger vitale parametre til grunn ved triage, reduserer variasjon mellom ulike brukere (8). Det er også vist at vitale parametre kan forutsi 
påfølgende behandlingsbehov og sykehusmortalitet $(4,8,9)$.

\section{Implementering}

Å innføre nye systemer i praksis byr på utfordringer, og det er derfor viktig med systematisk planlegging av hele prosessen for at resultatet skal bli vellykket. Det kan også være nyttig å se fasene $i$ en dynamisk prosess delt inn $i$ plan-, prosess-, og resultatfase (10).

I planleggingsfasen er det viktig å klargjøre mål, forventet resultat og betingelsene for gjennomføring (10). Vårt mål med innføring av systemet er at alle voksne pasienter blir gradert i henhold til METTSA i løpet av ti minutter etter ankomst til akuttmottaket, og at det foreligger dokumentasjon av gradering på alle pasienter. Det er viktig at pasienten opplever at de blir trygt ivaretatt ved akuttmottaket i Arendal.

En annen viktig forutsetting for å lykkes med innføring av METTS-A var at planene ble forankret i ledelsen. Vi fikk tildelt midler fra sykehusledelsen ved prosjektbeskrivelse og det ble satt sammen en tverrfaglig prosjektgruppe til å drive fram utviklingen.

I prosessfasen har vi foretatt valg av midler, strategi og gjennomføring (10). For å tilpasse dette systemet til vår enhet har vi omarbeidet Sahlgrensaka universitetssjukehus' akuttjournal til et dokumentasjonsskjema tilpasset vårt akuttmottak og vi startet opp med å oversette ESS-algoritmene til Norsk. For at sykepleiere og leger skulle bli kjent med dokumentasjonsskjemaet før det ble brukt systematisk i triage, tok vi i bruk en pilotutgave. Dette førte til konstruktive tilbakemeldinger på

\section{Et system som gir godt samsvar i graderinger, uavhengig av hvem som graderer, styrker kvaliteten på pasientmottak.}

pilotutgaven, som ble rettet opp i neste opptrykk. ESS-algoritmene ble også uformelt introdusert $\mathrm{i}$ personalgruppen lenge før vi satte i gang med opplæring i triage.

Akuttmottakets samhandlingsarena er sammensatt av aktører med ulike funksjoner i pasientforløpet, ikke bare i akuttmottaket, men også på tvers av enheter. For at arbeidsflyt og informasjonsflyt skal fungere optimalt ved bruk av METTS-A er det en forutsetning at alle parter kjenner systemet. Når systemet hadde begynte å ta form og de endringer det ville medføre var klarerte, startet et offensivt arbeid med å informere alle samarbeidsparter.

Personalgruppen i akuttmottaket er blitt orientert om prosjektets fremdrift i ulike sammenhenger gjennom hele prosessen. Hver og en fikk i tillegg opplæring i bruk av METTS-A som var tilpasset den rollen de skal ivareta i pasientbehandling. Til opplæring av personalet benyttet vi ressurspersoner i fagmiljøet.

Implementering av et system innebærer ikke bare endringer i arbeids- og informasjonsflyt, men også av funksjon og ansvar. Dette genererte arbeidet med endring $\mathrm{i}$ kvalitetsdokumenter i enheten.

For å tilrettelegge for triage var det nødvendig med noen bygningsmessige omdisponeringer og endringer for å gjøre plass for triageområdet. Erfaringene tilsier at slik endring tar svært lang tid i en stor organisasjon og må planlegges i lang tid på forhånd.

\section{Avslutning}

I resultatfasen må vi undersøke hvorvidt de ønskede mål og resultater er realisert. Vi må gjennomgå de erfaringer vi har høstet underveis i prosessen og se på eventuelle utilsiktede konsekvenser (10). Vårt prosjekt Triage i Akuttmottaket er inndelt i tre faser: 1) Undersøke baseline, 2) implementere METTS-A , og 3) oppsummere hvilke resultater det har gitt. Vi har gjort en baseline-undersøkelse som sier oss noe om hvordan pasientmottak og dokumentasjon var før innføring av METTS-A. Denne undersøkelsen skal vi gjenta når METTS-A er godt i gang og de fleste «barnesykdommene» over. Av erfaringen underveis i prosessen ser vi hvor enormt viktig det er med informasjon, innspill og deltagelse fra personalgruppen og samarbeidsparter underveis. En utfordring i prosjektledelse er å sortere og komme videre i prosessen inkludert de konstruktive innspill.

Vi har i dag en svært positivt innstilt personalgruppe og engasjert ledelse. Våre samarbeidsparter gir eksplisitt utrykk for at dette vil medføre en klar kvalitetsforbedring i akuttmottaket. Nå gjenstår det å bruke tiden på å høste erfaring med bruk av systemet og evaluere i forhold til våre mål.

\section{LITTERATUR}

1.MENS VI VENTER ...»Forsvarlig pasientbehandling i Akttmottakene?" Statens helsetilsyn. Februar 2008

2. Gjöranson K." Registrated nurse-led emergency department triage: organisation, allocation of acuity rating and triage decition making" Örebro Universitet, 2006

3. Gjöranson K , Ehrenberg A , Marklund B, Ehnfors M. Triage i Akuttmottakningen

4. Windgren B, Jourak M, Martinius A. Ny träffsäker triagemetod. METTS-A ger underlag för prioritering till rätt vårdnivå. Läkartidningen. 2008;105:201-4.

5. van der Wulp I, van Baar ME , Schrijvers AJP. Reliability and validity of the Manchester Triage System in general emergency department patient population in the Netherlands: result of a simulation study. Emerg. Med. j. 2008 jul:25 431-434

6. Widgren B, Person L, Martinius A. Manual Metts Medical Emergency Triage and Treatment System. Protokoll för Triage och Vårdprosess för pasienter på akutmottagningen. Versjon 1.6 Skarlänska universitetssjukehus

7. DEL 2 LOV 2. JULI 1999 NR. 61 OM SPESIALISTHELSETJENESTEN M.M. § 2-3. Plikt til forsvarlighet.

8. Tanbale P, Gimbel R, Kyriacous D, Adams J.Reliablity and validity of scores on The emergency department triage. Acad emerg Med 2004: jan. 11 59-65

9. Olsen T, Terent A, Lind L. Rapid Emergency Medicine score: a New prognostic tool for inhospital mortality in nonsurgical emergency department patients. Journal og internal Medicine 2004 255: 579-587

10. Remmen A. Teknologisk iværksettelse, Samfundet i teknologien. I: Rostgård M, Rimmen (red) Aalborg, Aalborg universitet 1990: kapittel 7 s. $143-160$ 